\title{
Effects of Carperitide on Contrast-Induced Acute Kidney Injury with a Minimum Volume of Contrast in Chronic Kidney Disease Patients
}

\author{
Naoki Okumura ${ }^{\mathrm{a}}$ Mutsuharu Hayashi ${ }^{\mathrm{a}, \mathrm{b}}$ Enyu Imai $^{\mathrm{c}}$ \\ Hideki Ishii ${ }^{a}$ Daiji Yoshikawa ${ }^{a}$ Yoshinari Yasuda $^{\text {b, } c}$ \\ Motomitsu Goto $^{\text {b, d }}$ Seiichi Matsuo ${ }^{c}$ Yutaka Oiso $^{d}$ \\ Toyoaki Murohara ${ }^{\text {a }}$
}

Departments of a Cardiology, ${ }^{\mathrm{b}} \mathrm{CKD}$ Initiatives Internal Medicine, ${ }^{\mathrm{C}}$ Nephrology, and

dEndocrinology and Diabetes, Nagoya University Graduate School of Medicine,

Nagoya, Japan

\section{Key Words}

Contrast-induced acute kidney injury $\cdot$ Carperitide $\cdot$ Chronic kidney disease $\cdot$ Contrast medium volume

\begin{abstract}
Background/Aims: Although contrast-induced acute kidney injury (CIAKI) is a major complication associated with angiography, the prophylaxis is not well established. Use of a low dose of carperitide for preventing CIAKI remains controversial. We examined the protective effect of carperitide on CIAKI after coronary angiography with a small contrast volume in chronic kidney disease (CKD) patients with coronary artery disease. Methods: We randomly assigned 112 consecutive patients to a carperitide or a control group. The contrast volume was kept under 150 $\mathrm{ml}$. The primary endpoint was the incidence of CIAKI defined by a serum creatinine of $\geq 25 \%$ or a serum creatinine of $\geq 0.5 \mathrm{mg} / \mathrm{dl}$ from baseline within $48 \mathrm{~h}$. The secondary endpoint was a change in renal function at 1 week after the procedure. Results: The baseline characteristics and contrast volumes (carperitide group: $67.4 \pm 38.2 \mathrm{ml}$ vs. control group: $64.8 \pm 20.5 \mathrm{ml}, \mathrm{p}=0.661$ ) were comparable in the two groups. The incidence of CIAKI was similar in the two groups (carperitide group: $8.5 \%$ vs. control group: $5.7 \%, p=0.564$ ). A multivariate analysis revealed that a hypotension $\geq 20 \mathrm{~mm} \mathrm{Hg}$ was a significant predictor of developing CIAKI in the carperitide
\end{abstract}

Mutsuharu Hayashi, MD, PhD

Department of Cardiology

Nagoya University Graduate School of Medicine

65 Tsurumai-cho, Syouwa-ku, Nagoya 466-8550 (Japan)

E-Mailmuhayasi@med.nagoya-u.ac.jp 
Okumura et al.: Effects of Carperitide on Contrast-Induced Acute Kidney Injury with a

Minimum Volume of Contrast in Chronic Kidney Disease Patients

group ( $p=0.015)$. The incidence of CIAKI in the carperitide group without hypotension was rare, but not significantly different (carperitide group: $2.4 \%$ vs. control group: $5.7 \%, p=0.432$ ). Conclusions: This study indicated that the use of a small contrast volume suppressed the incidence of $\mathrm{CIAKI}$ and that carperitide had no prophylactic effect against CIAKI. Our results also revealed the impact of hypotension on the development of CIAKI in the carperitide group.

Copyright $\odot 2012$ S. Karger AG, Basel

\section{Introduction}

Contrast-induced acute kidney injury (CIAKI) is one of the major critical complications of coronary angiography (CAG) and/or percutaneous coronary intervention (PCI), and is associated with increased morbidity and mortality $[1,2]$.

The overall incidence of CIAKI in patients with chronic kidney disease (CKD) is extremely higher, at $10-25 \%[3,4]$, than in the general population. Diabetes mellitus, high-dose administration of contrast media, hypotension, anemia, and CKD are reported as the risk factors for CIAKI [4]. To date, there is no sound evidence supporting the routine use of prophylactic drugs to prevent CIAKI; however, it is potentially possible to diminish the incidence by reducing the volume of contrast media.

Since recently, technical advances allow performing CAG or PCI with a very small amount of contrast media. The toxicity of contrast media on the kidneys is dose dependent [5], and a recent report revealed that a volume of contrast medium of $\geq 155 \mathrm{ml}$ is a risk for CIAKI [6].

The pathogenesis of CIAKI is considered to be mainly dependent on renal hypoperfusion and ischemia $[7,8]$. Carperitide, a member of the natriuretic peptide family with a vasodilating function $[9,10]$, was found to have various renoprotective effects, such as improvement of renal plasma flow, reducing the plasma levels of several vasoconstrictors [11-13]. Morikawa et al. [6] reported that the beneficial effect of low-dose carperitide on renal function is maintained for up to 1 month after contrast medium use. However, another study failed to prove any beneficial effect of carperitide on the incidence of CIAKI [14].

The aim of this prospective, randomized, open-label, blinded endpoint (PROBE) study was to determine whether low-dose carperitide has a prophylactic effect against CIAKI under CAG/PCI with a minimum volume of contrast medium in patients with CKD.

\section{Materials and Methods}

\section{Study Population}

We enrolled a total of 125 consecutive CKD patients undergoing CAG or PCI. CKD was defined as a baseline estimated glomerular filtration rate (eGFR) $<60 \mathrm{ml} / \mathrm{min} / 1.73 \mathrm{~m}^{2}$, which was calculated by the Modification of Diet in Renal Disease formula modified for Japanese subjects: $\mathrm{eGFR}=194 \times$ serum creatinine $\mathrm{e}^{-1.094} \times$ age $^{-0.287} \times 0.739$ (if female) $[15,16]$. The exclusion criteria included hypersensitivity to contrast media or carperitide; a baseline systolic blood pressure $<110 \mathrm{~mm} \mathrm{Hg}$; the use of vasopressors before the procedure; current hemodialysis; planned post-contrast medium dialysis; major surgery or contrast medium use within 10 days before the study; acute coronary syndrome; multiple myeloma; parenteral use of diuretics, and the administration of $\mathrm{N}$-acetylcysteine, metformin, sodium bicarbonate, fenoldopam, mannitol, or nonsteroidal anti-inflammatory drugs (NSAIDs). We excluded the patients who required cardiac mechanical support (intra-aortic balloon pumping or percutaneous cardiopulmonary support) during the procedure. 
Okumura et al.: Effects of Carperitide on Contrast-Induced Acute Kidney Injury with a

Minimum Volume of Contrast in Chronic Kidney Disease Patients

We calculated the sample size assuming a CIAKI rate of $20 \%$ in the control group based on the incidence rate previously reported in CKD patients undergoing CAG $[3,4]$. Also, we assumed that the incidence of CIAKI decreases to almost one seventh through the administration of carperitide [13]. Based on these assumptions, we calculated that 57 patients were needed in each treatment group to detect a statistically significant difference between treatment groups using the log-rank test with $\alpha=0.05$ (two-sided) and $1-\beta=0.80$.

The study protocol and chart reviews were approved by our institutional ethics committee. Written informed consent was given by all patients prior to the procedure.

\section{Study Protocol}

Patients were randomly assigned to receive either carperitide (Daiichi-Sankyo Co., Ltd., Tokyo, Japan) in addition to intravenous hydration with $1.0 \mathrm{ml} / \mathrm{kg} / \mathrm{h}$ of saline (carperitide group) or only hydration with saline (control group) for 12-18 h before and for $6 \mathrm{~h}$ after contrast administration. Carperitide was dissolved in a 5\% carbohydrate solution and adjusted to $0.025 \mu \mathrm{g} / \mathrm{kg} / \mathrm{min}$. Iohexol (Omnipaque 350; Daiichi-Sankyo Co., Ltd.), a nonionic, lowosmolality contrast medium, was used in all patients. When the systolic blood pressure decreased below $90 \mathrm{~mm} \mathrm{Hg}$, carperitide was reduced to half a dose. When we recognized a consistent decrease in the systolic blood pressure (to $<90 \mathrm{~mm} \mathrm{Hg}$ ) or when the patients' symptoms were dependent on blood pressure oscillations, we excluded the patients from this study.

The primary endpoint was the incidence of CIAKI defined as a $25 \%$ increase in creatinine or an increase in creatinine by $0.5 \mathrm{mg} / \mathrm{dl}$ from baseline at the maximum value obtained within $48 \mathrm{~h}$ after the procedure $[4,5]$. The serum creatinine and cystatin C levels were measured at 12-24 h before the procedure, and at 24-48 h and 1 week after the procedure. The secondary endpoint was the changes in the serum creatinine and serum cystatin $\mathrm{C}$ concentrations at 1 week after procedure.

\section{Statistical Analysis}

The STATA/SE11 software program was used for all statistical analyses. We tested the distribution of continuous variables for normality with a one-sample Kolmogorov-Smirnov test. Continuous variables were presented as the means (standard deviations), and differences between the two groups were evaluated by Student's unpaired $t$ test or the Wilcoxon test if the distribution was abnormal. Comparisons across the two groups were performed by the $\chi^{2}$ test. We used a logistic regression analysis for the multivariable analysis. After initial therapy, the statistical analysis was based on an intention-to-treat analysis.

\section{Results}

Seven patients (2 refused to participate in the study, 5 did not meet the inclusion criteria) did not participate in this study. Two patients with symptomatic hypotension were excluded because of their intolerance to carperitide. After CAG, 4 patients ( 3 who received a dose of contrast medium $>150 \mathrm{ml}$, and 1 who required intra-aortic balloon pumping) were excluded. Therefore, 112 patients were eligible for this study (carperitide group: $\mathrm{n}=59$, placebo group: $\mathrm{n}=53$ ) (fig. 1).

Table 1 shows the baseline clinical characteristics of the enrolled patients. There were no significant differences between the two groups. Also, the patients' baseline renal function was comparable.

The volume of contrast medium used (table 2) was similar in both groups (carperitide group: $67.4 \pm 38.2 \mathrm{ml}$ vs. control group: $64.8 \pm 20.5 \mathrm{ml}, \mathrm{p}=0.661$ ). When compared with the control group, carperitide infusion produced a significant decrease in the systolic blood pres- 
Fig. 1. Randomization and clinical diagnoses of all patients. $\mathrm{IABP}=$ Intra-aortic balloon pumping.

Minimum Volume of Contrast in Chronic Kidney Disease Patients

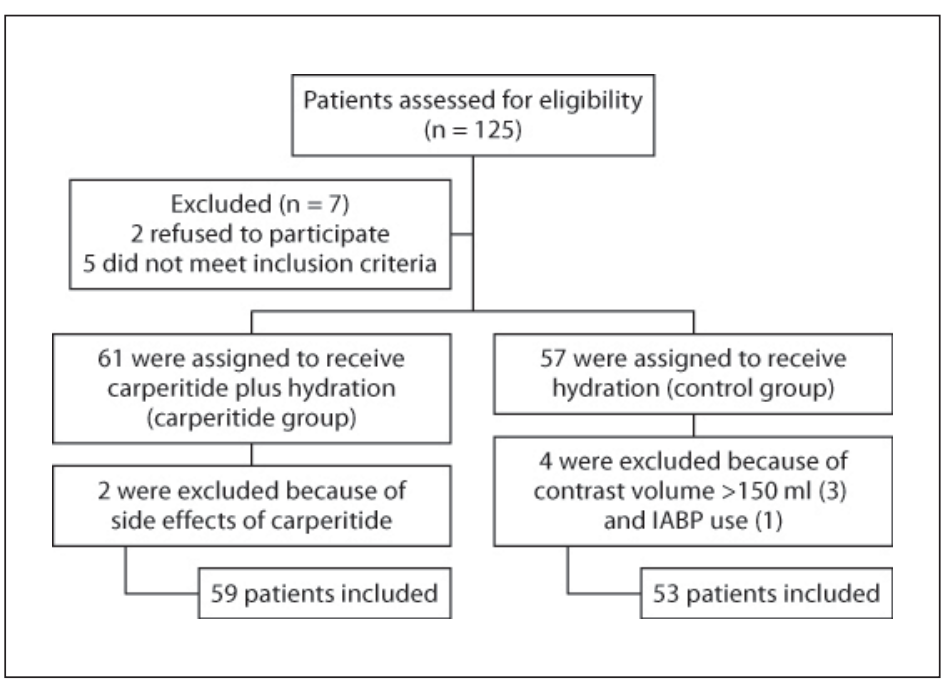

Table 1. Baseline characteristics of study patients

\begin{tabular}{llcc}
\hline & $\begin{array}{l}\text { Carperitide group } \\
(\mathrm{n}=59)\end{array}$ & $\begin{array}{l}\text { Control group } \\
(\mathrm{n}=53)\end{array}$ & p value \\
\hline Age, years & $74(8.9)$ & $73.0(6.3)$ & 0.566 \\
Male, \% & 68 & 83 & 0.080 \\
Body mass index & $23.9(3.1)$ & $23.6(3.4)$ & 0.682 \\
Systolic blood pressure, mm Hg & $129.9(17.6)$ & $135.1(20.7)$ & 0.152 \\
Hypertension, \% & 83 & 77 & 0.449 \\
Diabetes mellitus, \% & 59 & 45 & 0.137 \\
History of myocardial infarction, \% & 15 & 15 & 0.981 \\
History of congestive heart failure, \% & 8 & 9 & 0.859 \\
Medication, \% & & & 0.158 \\
$\quad$ ACE inhibitors & 18 & 8 & 0.513 \\
$\quad$ ARBs & 56 & 63 & 0.306 \\
$\quad$ Calcium channel blockers & 52 & 42 & 0.718 \\
$\quad$ Diuretics & 34 & 38 & 0.721 \\
$\quad$ Statins & 68 & 65 & 0.198 \\
LVEF, $\%$ & $62.6(12.4)$ & $59.0(15.7)$ & 0.121 \\
Current smoker, \% & 24 & 38 & \\
\hline
\end{tabular}

Data are presented as means (SD) for continuous variables, and percentages for categorical variables. $\mathrm{ACE}=$ Angiotensin-converting enzyme; $\mathrm{LVEF}=$ left ventricular ejection fraction .

sure at $12 \mathrm{~h}[-3.5(-7$ to 2$)$ vs. $-14(-20$ to -8.5$) \mathrm{mm} \mathrm{Hg}, \mathrm{p}<0.001]$. The incidence of a critical systolic blood pressure reduction, defined as a systolic blood pressure reduction $\leq-20 \mathrm{~mm}$ $\mathrm{Hg}$, was significantly higher in the carperitide group than in the control group $(\mathrm{p}<0.001)$.

There were no significant differences for the primary outcome of the development of CIAKI between the groups (carperitide group: $8.5 \%$ vs. control group: $5.7 \%, \mathrm{p}=0.564$ ) (fig. 2). Of importance, only an increase in serum creatinine $>25 \%$ occurred as an indicator of CIAKI, and there were no patients who developed CIAKI strictly defined as an increase in serum creatinine of $\geq 0.5 \mathrm{mg} / \mathrm{dl}$. 
Fig. 2. The incidence of CIAKI was a little higher in the carperitide group than in the control group, but the difference was not statistically significant.

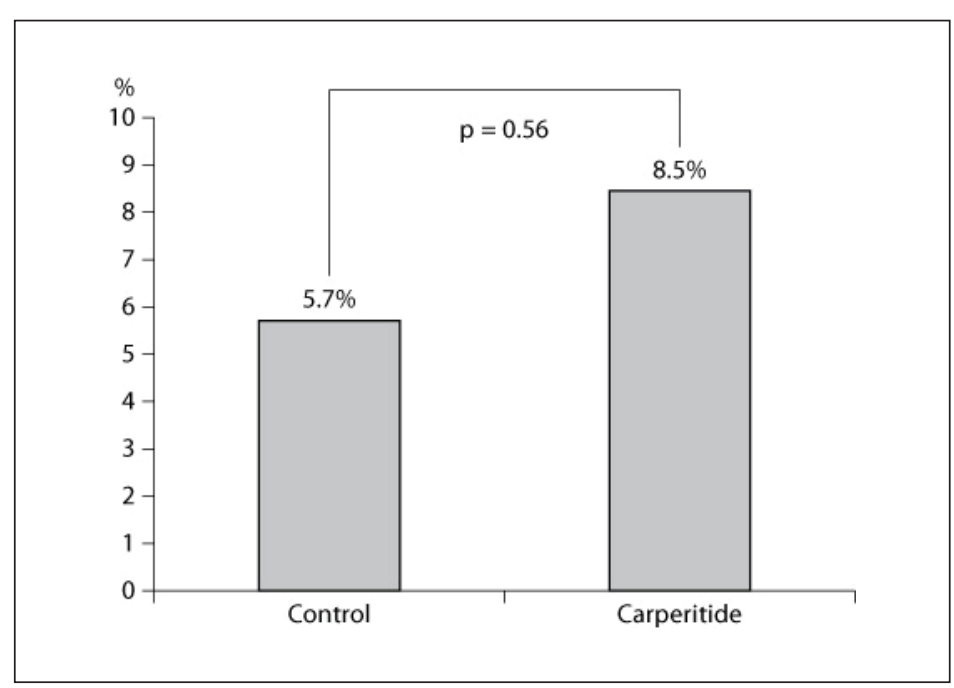

Table 2. Contrast volume and changes in blood pressure of study patients

\begin{tabular}{lllr}
\hline & $\begin{array}{l}\text { Carperitide group } \\
(\mathrm{n}=59)\end{array}$ & $\begin{array}{l}\text { Control group } \\
(\mathrm{n}=53)\end{array}$ & p value \\
\hline Contrast medium volume, $\mathrm{ml}$ & $67.4(38.2)$ & $64.8(20.5)$ & 0.661 \\
Change in systolic blood pressure, $\mathrm{mm} \mathrm{Hg}$ & $-14(-20$ to -8.5$)$ & $\begin{array}{c}-3.5(-7 \text { to }-2) \\
2\end{array}$ & $<0.001$ \\
Incidence of hypotension 1 , \% & 31 & $<0.001$ \\
\hline
\end{tabular}

Data are presented as means (SD) or medians (interquartile ranges) for continuous variables and percentages for categorical variables. ${ }^{1}$ Incidence of hypotension is defined as a systolic blood pressure reduction $\leq-20 \mathrm{~mm} \mathrm{Hg}$ from baseline.

According to the secondary endpoint, the adverse effects of contrast medium on renal function were also similar in both groups. Table 3 shows the changes in renal functional markers. In the carperitide group, there was a significant deterioration in the serum creatinine, eGFR, and serum cystatin C levels compared to the control group at $24-48 \mathrm{~h}$ after the administration of the contrast medium ( $\mathrm{p}=0.002,0.006,0.001$, respectively). In contrast, the serum creatinine level showed a tendency to decrease in the carperitide group at 1 week after contrast medium use, but not significantly so.

A univariate analysis of the incidence of CIAKI in the carperitide group revealed that hypotension defined as a severe systolic blood pressure reduction by $\leq-20 \mathrm{~mm} \mathrm{Hg}$ was a significant predictor [odds ratio (OR) $15.6(1.58-154.28), \mathrm{p}=0.019$ ] (table 4). When all variants of the patients' age, diabetes mellitus status, angiotensin II receptor blocker (ARB) and statin use, and hypotension detected by the univariate analysis were included in the multivariate model, hypotension was an independent predictor of the development of CIAKI in the carperitide group [OR 31.87 (1.93-525.58), $\mathrm{p}=0.015$ ]. Furthermore, all patients who developed CIAKI in the carperitide group and $75 \%$ of the patients who developed CIAKI in both groups were treated with calcium channel blockers. Although the incidence of CIAKI in the carperitide group without hypotension was low, it was comparable to that in the placebo group (2.4 vs. $5.7 \%$, respectively, $\mathrm{p}=0.432$ ) (fig. 3 ). 
Fig. 3. The incidence of CIAKI was higher in the control group than in the carperitide group without severe blood pressure reduction, but the difference was not statistically significant.

Okumura et al.: Effects of Carperitide on Contrast-Induced Acute Kidney Injury with a

Minimum Volume of Contrast in Chronic Kidney Disease Patients

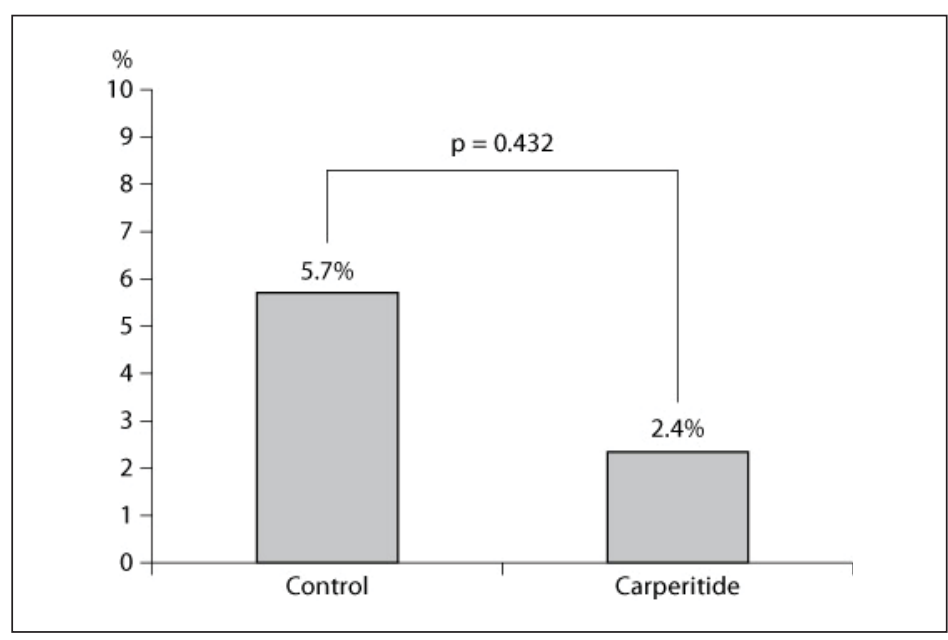

Table 3. Changes from baseline in serum creatinine, eGFR, and serum cystatin C

\begin{tabular}{|c|c|c|c|}
\hline & $\begin{array}{l}\text { Carperitide group } \\
(\mathrm{n}=59)\end{array}$ & $\begin{array}{l}\text { Control group } \\
(\mathrm{n}=53)\end{array}$ & $\mathrm{p}$ value \\
\hline \multicolumn{4}{|l|}{ Serum creatinine, $\mathrm{mg} / \mathrm{dl}$} \\
\hline Baseline & $1.16(0.99-1.27)$ & $1.18(1-1.44)$ & 0.493 \\
\hline Change within $48 \mathrm{~h}$ & $0.05(-0.03$ to 0.13$)$ & $-0.03(-0.08$ to 0.07$)$ & 0.002 \\
\hline Change at 1 week & $-0.03(-0.09$ to 0.04$)$ & $0.01(-0.06$ to 0.07$)$ & 0.054 \\
\hline \multicolumn{4}{|l|}{$\mathrm{eGFR}, \mathrm{ml} / \mathrm{min} / 1.73 \mathrm{~m}^{2}$} \\
\hline Baseline & $44.4(9.2)$ & $45.4(10.4)$ & 0.574 \\
\hline Change within $48 \mathrm{~h}$ & $-2.0(6.1)$ & $0.8(4.3)$ & 0.006 \\
\hline Change at 1 week & $0.9(5.6)$ & $-0.4(4.3)$ & 0.169 \\
\hline \multicolumn{4}{|l|}{ Serum cystatin $\mathrm{C}, \mathrm{mg} / \mathrm{l}$} \\
\hline Baseline & $1.47(1.26-1.64)$ & $1.36(1.23-1.7)$ & 0.630 \\
\hline Change within $48 \mathrm{~h}$ & $0.09(-0.01$ to 0.18$)$ & $-0.03(-0.11$ to 0.07$)$ & 0.001 \\
\hline Change at 1 week & $-0.01(-0.08$ to 0.04$)$ & $-0.01(-0.1$ to 0.05$)$ & 0.242 \\
\hline
\end{tabular}

Data are presented as means (SD) or medians (interquartile ranges).

Table 4. Univariate and multivariate analysis for CIAKI in the carperitide group

\begin{tabular}{|c|c|c|c|c|c|c|}
\hline & \multicolumn{2}{|c|}{ CIAKI, \% } & \multicolumn{2}{|l|}{ Univariate analysis } & \multicolumn{2}{|l|}{ Multivariate analysis } \\
\hline & $(+)$ & $(-)$ & OR 95\% CI & $p$ value & OR 95\% CI & $\mathrm{p}$ value \\
\hline Age $>70$ years & 80 & 78 & $1.14(0.12-11.21)$ & 0.909 & $1.08(0.1-33.16)$ & 0.960 \\
\hline Diabetes mellitus & 80 & 57 & $2.97(0.31-28.35)$ & 0.325 & $10.49(0.40-275.51)$ & 0.159 \\
\hline Dyslipidemia & 80 & 69 & $1.83(0.19-17.71)$ & 0.599 & & \\
\hline Hypertension & 80 & 82 & $0.91(0.09-9.03)$ & 0.940 & & \\
\hline ARBs & 20 & 59 & $0.17(0.02-1.64)$ & 0.126 & $0.78(0-1.61)$ & 0.099 \\
\hline Statins & 60 & 70 & $0.63(0.10-4.15)$ & 0.630 & $0.22(0.13-3.35)$ & 0.274 \\
\hline Incidence of hypotension ${ }^{1}$ & 80 & 30 & $15.6(1.58-154.28)$ & 0.019 & $31.87(1.93-525.58)$ & 0.015 \\
\hline $\operatorname{LVEF}(\geq 40 \%)$ & 80 & 93 & $0.32(0.29-3.59)$ & 0.333 & & \\
\hline Contrast medium $>65 \mathrm{ml}$ & 40 & 35 & $1.23(0.19-8.00)$ & 0.830 & & \\
\hline History of myocardial infarction & 20 & 15 & $1.44(0.14-14.57)$ & 0.758 & & \\
\hline
\end{tabular}

$\mathrm{LVEF}=$ Left ventricular ejection fraction; $\mathrm{CI}$ = confidence interval.

${ }^{1}$ Incidence of hypotension is defined as a systolic blood pressure reduction $\leq-20 \mathrm{~mm} \mathrm{Hg}$ from baseline. 


\section{Discussion}

The pathogenesis of CIAKI is considered to be linked to the cytotoxic effects of contrast media and renal vasoconstriction. In the present study, we showed that CAG with low-dose contrast medium decreased the incidence of CIAKI by about $50 \%$ compared to previous reports and none of our CKD patients with CAG developed strictly defined CIAKI ( $\geq 0.5 \mathrm{mg} /$ $\mathrm{dl}$ serum creatinine), which is reported to be a more sensitive definition for mortality and morbidity in patients with CIAKI [17]. Carperitide, a renal-specific vasodilator, has been reported to have preventive effects on contrast-induced renal injury because of improvement of renal perfusion [18]. Contrary to the previously reported protective effects of carperitide, our current results did not demonstrate the advantages for CIAKI. A sub-analysis of CIAKI in the carperitide group showed an impact of hypotension, which was suggested to disturb the renoprotective effects of carperitide. Also, our sub-analysis revealed that combination therapy using calcium channel antagonists with carperitide could potentially predict the development of CIAKI. Glomerular hypoperfusion induced by systemic arterial pressure reduction due to treatment with dual vasodilators is suggested to result in glomerular dysfunction within $48 \mathrm{~h}$ after contrast medium use.

Mehran et al. [19] reported the utility of a CIAKI risk stratification score based on 8 available variables, and we can improve the procedure-related factors including the contrast volume. The present study indicates that decreasing the volume of contrast medium is indispensable for the prophylaxis of CIAKI, especially in CKD patients. When the contrast volume is suppressed to $<100 \mathrm{ml}$, a critical blood pressure reduction exerts adverse effects on the development of CIAKI. The results of our sub-analysis emphasize the need for avoiding excessive use of vasodilators in order to maintain the renal circulation. As the incidence of hypotension was higher in the carperitide group, carperitide use should be avoided when the contrast medium volume is suppressed. The determination of an adaptable dose of carperitide, without hypotension, is essential for an effective and safe use of carperitide in patients with CAG/PCI.

\section{Study Limitations}

First, the diagnosis of CIAKI depended on the peak value of the serum creatinine concentration within $48 \mathrm{~h}$ after contrast medium use [20]. However, because of our institutional limitations concerning the frequency and timing of blood collection, the degree of the elevation of creatinine might have been underestimated. Second, this study was a singlecenter study and was not blinded. Third, the incidence of CIAKI was lower than predicted under procedures using a small amount of contrast medium.

\section{Acknowledgments}

The authors are indebted to all technicians, nurses, and doctors in the catheterization laboratories, the intensive care unit, and on the wards for their ongoing support.

\section{Disclosure Statement}

The authors declare that they have no conflicts of interest. 


\section{References}

1 Levy EM, Viscoli CM, Horwitz RI: The effect of acute renal failure on mortality. A cohort analysis. JAMA 1996;275:1489-1494.

-2 Weisbord SD, Chen H, Stone RA, Kip KE, Fine MJ, Saul MI, Palevsky PM: Associations of increases in serum creatinine with mortality and length of hospital stay after coronary angiography. J Am Soc Nephrol 2006;17:2871-2877.

-3 Aspelin P, Aubry P, Fransson SG, Strasser R, Willenbrock R, Berg KJ: Nephrotoxic effects in high-risk patients undergoing angiography. N Engl J Med 2003;348:491-499.

-4 McCullough PA: Contrast-induced acute kidney injury. J Am Coll Cardiol 2008;51:1419-1428.

5 Maeder M, Klein M, Fehr T, Rickli H: Contrast nephropathy: review focusing on prevention. J Am Coll Cardiol 2004;44:1763-1771.

-6 Morikawa S, Sone T, Tsuboi H, Mukawa H, Morishima I, Uesugi M, Morita Y, Numaguchi Y, Okumura K, Murohara T: Renal protective effects and the prevention of contrast-induced nephropathy by atrial natriuretic peptide. J Am Coll Cardiol 2009;53:1040-1046.

7 Brezis M, Rosen S: Hypoxia of the renal medulla - its implications for disease. N Engl J Med 1995; 332:647-655.

-8 Block CA, Manning HL: Prevention of acute renal failure in the critically ill. Am J Respir Crit Care Med 2002;165:320-324.

-9 Kangawa K, Matsuo H: Purification and complete amino acid sequence of alpha-human atrial natriuretic polypeptide (alpha-hANP). Biochem Biophys Res Commun 1984;118:131-139.

-10 Proctor KG, Bealer SL: Selective antagonism of hormone-induced vasoconstriction by synthetic atrial natriuretic factor in the rat microcirculation. Circ Res 1987;61:42-49.

- 11 Sandok EK, Lerman A, Stingo AJ, Perrella MA, Gloviczki P, Burnett JC Jr: Endothelin in a model of acute ischemic renal dysfunction: modulating action of atrial natriuretic factor. J Am Soc Nephrol 1992;3:196-202.

-12 Emori T, Hirata Y, Imai T, Eguchi S, Kanno K, Marumo F: Cellular mechanism of natriuretic peptides-induced inhibition of endothelin-1 biosynthesis in rat endothelial cells. Endocrinology 1993; 133:2474-2480.

-13 Wada A, Tsutamoto T, Matsuda Y, Kinoshita M: Cardiorenal and neurohumoral effects of endogenous atrial natriuretic peptide in dogs with severe congestive heart failure using a specific antagonist for guanylate cyclase-coupled receptors. Circulation 1994;89:2232-2240.

-14 Kurnik BR, Allgren RL, Genter FC, Solomon RJ, Bates ER, Weisberg LS: Prospective study of atrial natriuretic peptide for the prevention of radiocontrast-induced nephropathy. Am J Kidney Dis 1998; 31:674-680.

-15 Imai E, Horio M, Nitta K, Yamagata K, Iseki K, Hara S, Ura N, Kiyohara Y, Hirakata H, Watanabe T, Moriyama T, Ando Y, Inaguma D, Narita I, Iso H, Wakai K, Yasuda Y, Tsukamoto Y, Ito S, Makino $\mathrm{H}$, Hishida A, Matsuo S: Estimation of glomerular filtration rate by the MDRD study equation modified for Japanese patients with chronic kidney disease. Clin Exp Nephrol 2007;11:41-50.

- 16 Matsuo S, Imai E, Horio M, Yasuda Y, Tomita K, Nitta K, Yamagata K, Tomino Y, Yokoyama H, Hishida A: Revised equations for estimated GFR from serum creatinine in Japan. Am J Kidney Dis 2009;53:982-992.

-17 Ferrario F, Barone MT, Landoni G, Genderini A, Heidemperger M, Trezzi M, Piccaluga E, Danna P, Scorza D: Acetylcysteine and non-ionic isosmolar contrast-induced nephropathy - a randomized controlled study. Nephrol Dial Transplant 2009;24:3103-3107.

-18 Valsson F, Ricksten SE, Hedner T, Lundin S: Effects of atrial natriuretic peptide on acute renal impairment in patients with heart failure after cardiac surgery. Intensive Care Med 1996;22:230-236.

-19 Mehran R, Aymong ED, Nikolsky E, Lasic Z, Iakovou I, Fahy M, Mintz GS, Lansky AJ, Moses JW, Stone GW, Leon MB, Dangas G: A simple risk score for prediction of contrast-induced nephropathy after percutaneous coronary intervention: development and initial validation. J Am Coll Cardiol 2004;44:1393-1399.

-20 Andrew E, Berg KJ: Nephrotoxic effects of X-ray contrast media. J Toxicol Clin Toxicol 2004;42: $325-332$. 